\title{
DOI https://doi.org/10.30525/978-9934-26-041-4-89
}

\section{ТЕХНОЛОГІЯ АСОЦІАТИВНОГО НАВЧАННЯ ІНОЗЕМНИХ МОВ: ПЕРСПЕКТИВИ І ВИКЛИКИ}

\author{
Гусак Л. Є. \\ доктор педагогічних наук, професор, \\ професор кафедри іноземних мов гуманітарних спечіальностей \\ Волинський національний університет імені Лесі Украйнки \\ Гедз С. Ф. \\ кандидат філологічних наук, доцент, \\ доиент кафедри іноземних мов гуманітарних спеціальностей \\ Волинський національний університет імені Лесі Украӥнки \\ Смалько Л. $\mathbf{\epsilon .}$ \\ кандидат педагогічних наук, доцент, \\ доцент кафедри іноземних мов гуманітарних спеціальностей \\ Волинський національний університет імені Лесі Украӥнки \\ м. Луиььк, Украӥна
}

Широкомасштабне залучення України до різних світових організацій і світового співтовариства, а також поступове входження України в єдиний європейський освітній простір у межах Загальноєвропейських рекомендацій [2] вимагають впровадження та розвитку нових технологій у навчанні.

Вивчення іноземних мов $\epsilon$ невід'ємною частиною навчальновиховного процесу. Відповідно до Концепції навчання іноземних мов, Державних стандартів початкової та базової освіти, програми 3 іноземної мови, загальноєвропейських рекомендацій формування комунікативної компетентності учнів $\epsilon$ основною метою навчання іноземної мови. Сьогодні на різних рівнях піднімається питання створення сучасного навчально-методичного забезпечення, визначення напрямів інтеграції іноземної мови у дитячі види діяльності, забезпечення наступності у навчанні дошкільнят та молодших школярів, впровадження інноваційних, зокрема ігрових технологій.

Щоб допомогти дитині розвинути свою особистість, творчий потенціал зацікавити навчанням та навчити вчитися, педагоги повинні залучати учнів до різних видів діяльності (ігрової, малювання, конструювання, експериментування тощо). Необхідність творчого навчання молодших школярів із першого класу зумовила активний 
пошук способів розвитку всебічних резервних можливостей особистості завдяки задіянню у процесі навчання обох півкуль головного мозку, які відповідають і за емоційну (афективну), і за інтелектуальну (когнітивну) сфери учнів початкової школи.

Саме такою технологією навчання учнів початкових класів $\epsilon$ технологія асоціативного навчання іноземної мови молодших школярів.

Поняття «асоціація» має давню історію. Його дефініція та трактування розпочинається 3 давньогрецької філософської науки. Так, Платон вказував на те, що асоціації виникають при згадуванні за схожістю та суміжністю. Аристотель акцентував увагу на тому, що асоціації виникають тоді, коли образ виникає без видимої на те причини, мимовільно. Діти сприймають світ переважно образами. Мова мозку - це створення образів, що спонукає до розвитку уяви, пам'яті й, загалом, розумової діяльності. Про це згадується у праці М. Зиганова й В. Козаренка під терміном «мнемоніка», який тісно пов'язаний 3 асоціативним навчанням.

Особливу увагу процесам формування асоціацій на прикладах дослідження мнемічних процесів приділяв Г. Еббінгауз. Вивчення ним асоціативної природи заучування і забування вважається визнаним прикладом геніальності досліджень у психології [5, с.104].

В українській лінгвістиці психолінгвістичні аспекти вивчення вербальних асоціацій ще потребують комплексного та цілісного розвитку, зокрема в рамках теорії міжкультурної комунікації. Психолінгвістичні дослідження асоціативного спрямування знайшли відображення у праці М. Муравицької, яка здійснила психолінгвістичний аналіз лексичної омонімії, синонімії та полісемії [3, с. 59-67], Н. Бутенко досліджувала вербальні асоціації («Словник асоціативних норм української мови» (1979), «Словник асоціативних означень іменників в українській мові» (1989), Д. Терехова комплексно досліджувала соматизми у близькоспоріднених мовах, порівнювала спільне та відмінне в семантичних асоціаціях носіїв цих мов («Особливості сприйняття лексичної семантики слів (психолінгвістичний аспект)») [4]. У 2001 р. Т. Ковалевським, Г. Сологуб та О. Ставченко впорядкований i виданий «Асоціативний словник української рекламної лексики» [1].

Варті уваги дисертаційні роботи О. Горошко та У. Марчук, пов'язані 3 дослідженням вербальних асоціацій в галузі мовознавства, а також дисертації Р. Ібрагімової та Н. Маркової, присвячені проблемам розвитку мовної діяльності молодших школярів на основі асоціативної уяви.

Для нас асоціативна психологія важлива насамперед тим, що вона дає можливість реалізувати асоціативне навчання учнів початкової 
школи. Органічне поєднання інтелектуально-лінгвістичної діяльності дитини 3 iї інтенсивним розвитком рухово-кінестетичної сфери обгрунтовується теорією асоціативного засвоєння. У межах цієї теорії розроблено і використано метод асоціативних символів, в основу якого покладено імітаційну рухову діяльність.

Метод асоціативних символів - мова рухів, жестів, міміки, мова нашого тіла, кодова мова уявлень і асоціацій. Це ігровий метод, який покращує сприймання i відтворення інформації, спираючись на властиве кожній дитині вміння уявляти і фантазувати. За допомогою яскравої дитячої уяви створюються образи будь-якої лексичної чи граматичної одиниці. Дитина набагато швидше запам'ятовує слово, якщо воно пов'язане 3 конкретним образом чи дією. Метод асоціативних символів передбачає навчання через імітацію, максимально наближену до реальності.

Створюючи разом із дітьми на заняттях асоціативні образи-символи, ми здійснюємо спробу адаптувати своєрідну мову тіла до процесу вивчення англійської мови у початковій школі.

Новизною асоціативного навчання $\epsilon$ те, що лексичний матеріал подається не традиційно, а 3 використанням методу асоціативних символів, який звільняє учнів від постійного нудного заучування нових слів i висловів та перетворює складний навчальний процес запам'ятовування мовного матеріалу в задоволення. Своєрідність навчання полягає в тому, що воно допомогає вчителям та батькам навчати дітей англійської мови в цікавій, легкодоступній, часто в жартівливій формі.

Представлена методика розроблена та апробована із застосуванням ігрового, комунікативно-діяльнісного, соціокультурного та особистісно орієнтованого підходів до розвитку молодших школярів.

В основу інноваційної технології асоціативного навчання молодших школярів, яка базується на принципі природовідповідності, покладено використання асоціативних символів, що створює умови, максимально наближені до життєвих ситуацій, та робить процес навчання доступним та невимушеним.

Методика використання асоціативних символів, яка застосовується у процесі асоціативного навчання, безпосередньо впливає на розвиток творчих здібностей, адже метою асоціативного мислення $є$ отримання нових оригінальних ідей, створення смислових зв'язків, стимуляція уяви, покращення запам'ятовування.

Інтенсивне застосування асоціативного навчання у процесі вивчення учнями початкової школи іноземних мов дозволяє адаптувати цей досвід при вивченні інших навчальних дисциплін. Крім того, асоціативне навчання молодших школярів як самодостатня технологія потребує наукового узагальнення та прикладного впровадження. 


\title{
Література:
}

1. Асоціативний словник української рекламної лексики / упор. Т. Ю. Ковалевський, Г. Д. Сологуб, О. В. Ставченко. Одеса, 2001. - $116 \mathrm{c.}$

2. Загальноєвропейські рекомендації з мовної освіти: вивчення, викладання, оцінювання/ Наук. ред. укр. вид. С. Ніколаєва. - К.: Ленвіт, 2003. - 273 с.

3. Муравицька М. П. Психолінгвістичний аналіз лексичної омонімії / М. П. Муравицька // Мовознавство. - 1975. - № 3. - С. 59-67.

4. Терехова Д. І. Особливості сприйняття лексичної семантики слів (психолінгвістичний аспект): [монографія] / Д. І. Терехова. - К.: Видавничий центр КДЛУ, 2000. - 244 с.

5. Шульц Д. П. История современной психологии: пер. с англ. А. В. Говорунов, В. И. Кузин, Л. Л. Царук / под ред. А.Д. Наследова / Д. П. Шульц, С. Э. Шульц. - СПб.: Евразия, 1998. - 528 с.- с. 104

\section{DOI https://doi.org/10.30525/978-9934-26-041-4-90}

\section{СУЧАСНІ ТЕХНОЛОГІЇ В МЕТОДИЦІ ВИКЛАДАННЯ УКРАЇНСЬКОЇ МОВИ ЯК ІНОЗЕМНОЇ}

\author{
Дегтярьова Т. 0. \\ кандидат філологічних наук, \\ доиент кафедри мовної підготовки іноземних громадян \\ Сумський державний університет \\ Дядченко Г. В. \\ кандидат філологічних наук, \\ старший викладач кафедри мовної підготовки іноземних громадян \\ Сумський державний університет \\ м. Суми, Украӥна
}

Дієвим імпульсом для появи різних підходів до навчання іноземних мов на сучасному етапі стала зміна стану суспільства, процес глобалізації. За останні десятиліття світ різко змінив звичну систему координат. Це стосується не тільки зовнішнього боку життя та політичної ситуації, а й базових цінностей, життєвих настанов і звичок людей. Ніколи в історії людства зміни не відбувалися в такому 